\title{
Analysis of Macroeconomic Influence Return on Assets Banking Study on Conventional Commercial Banks in Indonesia for the Year 2018-2020
}

\author{
Tegar Prasetya and Hakiman Thamrin
}

\section{ABSTRACT}

This study aims to analyze the effect of macroeconomic variables on the return on banking assets. The data processing method used by the researcher is using the Vector Error Correction Model (VECM) as a data analysis tool and this study confirms that the extent to which it examines the positive and significant influence between macroeconomic variables on the return on banking assets. The data obtained is secondary data based on financial statements within a period of 3 years using monthly time series data. The results of this study indicate that there is a positive and significant effect on the exchange rate and CPI variables while it is negative and significant on the inflation, interest rate and IPI variables resulting from the long-term VECM estimation. While the results show that there is a positive and significant effect on the interest rate and CPI variables and a significant negative on the inflation variable, positive and insignificant on the exchange rate variable, negative and insignificant on the IPI variable on the ROA of the short-term VECM estimation results. The results of the measurement of the composition or contribution of the influence of the independent variable on the dependent variable show the interest rate variable with a value of 4.11\% in the 10th period obtained through the results of the decomposition variance (VD) test on the return on assets (ROA) of banking studies at Conventional Commercial Banks in Indonesia.

Keywords: Banking Performance, Macroeconomic Conditions, ROA, VECM.

\section{INTRODUCTION}

The role of banks as intermediary institutions in a country and profitable institutions in the financial industry should be able to read and understand the financial situation that occurs. Market conditions that influence this are illustrated in banking performance indicators, especially in 2018-2020.

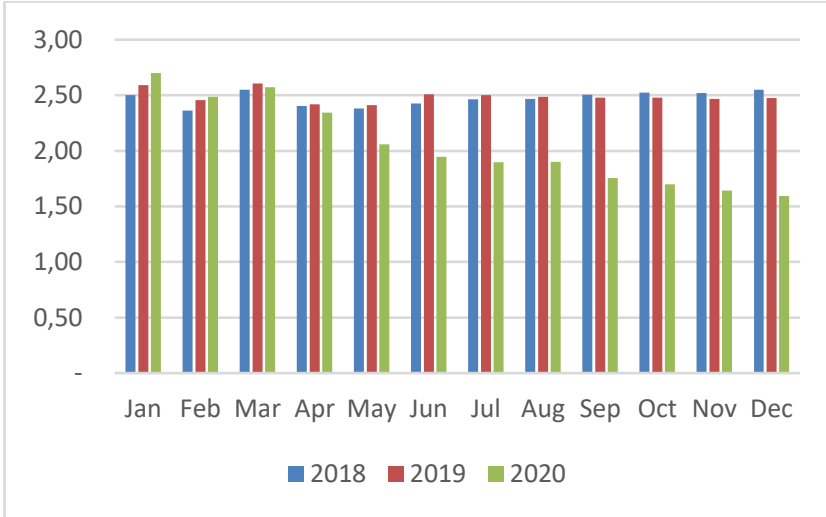

Fig. 1. Commercial Bank Performance Achievement Report ROA Performance Financial Services Unit Indicators (2018-2020).

Fig. 1 shows that the ROA of conventional commercial banks has decreased from year to year wherein in 2018 it was
Submitted : September 22, 2021

Published : October 31, 2021

ISSN: $2507-1076$

DOI: $10.24018 /$ ejbmr.2021.6.5.1118

Tegar Prasetya*

Universitas Mercu Buana, Indonesia.

(e-mail: tegarprasetya1992@gmail.com)

Hakiman Thamrin

Universitas Mercu Buana, Indonesia.

(e-mail:

hakimanthamrin@ mercubuana.ac.id)

*Corresponding Author
$2.55 \%$, while in 2019 it was $2.47 \%$ or smaller than in 2018 . When entered in the 3rd quarter of 2020 performance commercial banks on the ROA indicator show $1.76 \%$, this is an indication that the ability of banks to earn profits in 2020 as a whole has decreased.

In general, macroeconomic variables which are regularly used as determinants of financial institution overall performance from numerous researches are countrywide earnings or monetary increase, inflation, and hobby rates, [1]-[6] used the variables of monetary increase and inflation. Meanwhile, withinside the studies of [7]-[9] brought the change price variable two other measures that are often discussed related to bank performance that is often used return on assets (ROA) and return on equity or ROE [10][13].

Two different measures which are regularly mentioned associated with financial institution overall performance this is regularly used (ROA) [14].

In addition to the use of ROA [15], [16] brought the variable net interest margin (NIM) as overall performance proxy. It isn't the same as the researchers above [17], and [18] the use of the non-performing loan (NPL) variable as a hallmark of financial institution overall performance. 


\section{THEORETICAL REVIEW}

\section{A. Return on Asset (ROA)}

ROA (return on assets) is the ratio of net profit after tax to assess how big the rate of return from assets owned by the company. A negative ROA is due to the company's profit in a negative condition or a loss. This shows the ability of the invested capital as a whole has not been able to generate profits [19].

This ratio measures how effective the company is in utilizing existing economic resources to generate profits. To calculate ROA:

$$
\text { ROA }=\frac{\text { Net Profit }}{\text { Total Assets }} \times 100 \%
$$

\section{B. Inflation}

Inflation has a very diverse definition that can be found in the economic literature. This diversity of definitions of inflation also occurs because of the very close relationship between inflation and economic sectors, so that it creates various types of understanding and different views on inflation, including in addressing the problems caused by inflation. Inflation in a broad sense is an increase in prices that occurs in general and continuously in connection with the existence of a market mechanism. Inflation is a phenomenon and an economic dilemma for all countries because the decline in people's purchasing power will be followed by a decrease in the real value of the country's currency. The definition of inflation according to some experts is as follows:

Inflation is a general and continuous tendency to increase prices. When the price of one or more goods rises, it cannot be said to be inflation. However, if the price of goods rises widely and causes an increase in most of the other goods then it can be said to be inflation [20].

\section{Interest Rate}

Definition of interest for banks as financial intermediaries is the price of money in buying and selling transactions. The interest charged by the bank is an administrative fee, rental fee, reserves in case of bad credit, and inflation reserves [21].

So, in practice bank interest can be divided into two forms, namely, deposit interest; where interest is given to customers as compensation for money deposits in the bank and is the price to be paid by the bank to its customers and interest on loans, where the price that must be paid by the borrowing customer to the bank. Both types of interest are the main components of cost and income factors for conventional banks. Deposit interest is a cost for the bank while loan interest is income for the bank received from customers. In order to achieve the final target of monetary policy, Bank Indonesia implemented a monetary policy framework through controlling interest rates (interest-rate targets).

The Bank Indonesia interest rate, known as the BI-Rate, is set by Bank Indonesia, and announced to the public by the Board of Governors of Bank Indonesia at every monthly Board of Governors Meeting and has implications for monetary operations carried out by Bank Indonesia through liquidity management in the money market to achieve operational targets of monetary policy.

\section{Exchange Rate}

According to the Directorate of Economic Research and Monetary Policy of Bank Indonesia, the development of the exchange rate, starting in 1970, can be divided into 3 periods in accordance with the application of various exchange rate systems in each period. In each of these periods, basically, the exchange rate created is expected to be in line with the direction of economic policy when applied in both micro and macro aspects. The exchange rate system is as follows:

Fixed Exchange Rate System (Fixed Exchange Rate System). This system was motivated by the chaos of the world economic conditions as a result of the post-second world war. In 1944 there were forty-four States met in Bretton Woods, New Hampshire, United States of America and then agreed on several things, including the following: require a standard exchange rate between various currencies against the United States dollar, and between the dollar and gold at the level of $\$ 35$ per cent. ounce. All participating countries will use gold or dollars as the largest part of their international reserves, and they are entitled to sell these dollars for gold at the official price in the Federal Reserve. The central bank can intervene in order to maintain the balance of its foreign exchange reserves.

\section{E. Managed Exchange Rate System}

In this system, the Central Bank can intervene in the market to influence the movement of foreign exchange rates. This intervention is usually carried out because the movement of foreign exchange rates is considered unfavorable for the country's economy.

\section{F. Consumer Price Index (CPI)}

The CPI provides information on the average change in the price of a fixed group of goods/services that are generally consumed by households within a certain period of time. Changes in the CPI from time to time describe the rate of increase (inflation) or the rate of decline (deflation) of the prices of goods/services for daily household needs.

Calculation of CPI:

$$
\mathrm{CPI}=\{(\text { value } \times \text { weight }) /(\text { cost }-1 \times \text { weightt }-1)\} \times 100
$$

where

$\mathrm{t}=$ year calculated;

$\mathrm{t}-1$ = base year.

\section{G. Industrial Production Index (IPI)}

The IPI is usually released to the market on a monthly basis, about 16 days after the month. study ends. Release time is 9:15 a.m. US Eastern Time. The data is released on the Federal Reserve Bank's web page and also on independent news feeds from Bloomberg and Reuters Thomas.

According to the Central Bureau of Statistics, the management industry is an economic activity that carries out the activity of changing a basic good mechanically, chemically, or by hand so that it becomes a finished or semifinished product, and/or goods of less value into goods of higher value, and more in nature. close to the end user. Industrial services are industrial activities that serve the needs of other parties. Company or industrial business is a business unit that carries out economic activities, aiming to produce 
goods or services, located in a certain building or location.

\section{RESEARCH METHODS}

This research is a quantitative study with the secondary data type (monthly time series) taken from the Indonesian Economic and Financial Statistics (SEKI-BI) contained in the banking, Economic, and Trade performance reports of the Central Statistics Agency (BPS) and the Financial Services Authority (OJK) during the period January 2018 to December 2020. The data analysis technique of this research uses Evies11. The population in this study are banking companies and the sample of this research is Conventional Commercial Banks in Indonesia. This research was taken by using the purposing sampling method. criteria for sampling data include:

a. Banking Companies (Conventional Commercial Banks in Indonesia) in 2018 - 2020 consisting of 4 state-owned banks, 27 Regional Development Banks, 70 Joint Venture Banks, and 8 foreign banks with a total of 109 conventional commercial banks contained in the OJK SPI report.

b. The ROA banking financial performance report data during the research period, 2018, 2019, and 2020 are contained in the OJK SPI Report.

c. Macroeconomic data (Inflation, Interest Rates, Exchange Rates, CPI, and GDP) for the research period, 2018, 2019, and 2020, are available in BPS and BI.

\section{FINDING AND DISCUSSION}

\section{A. Unit Root Test}

Test Stationarity testing is obtained from the view of the graph and choleogram which is still subjective from every researcher who sees it. The unit root test is a formal test in stationarity testing pioneered by Dickey Fuller. The unit root test method used in this study is the Augmented Dickey Fuller (ADF) method:

TABLE I: AUGMENTED DiCKEY-FULLER (ADF) ESTIMATION RESULTS AT INTERCEPT-LEVEL

\begin{tabular}{ccccc}
\hline \multirow{4}{*}{ Variable } & \multicolumn{4}{c}{ ADF Statistic } \\
\cline { 2 - 5 } & t-statistic & $\begin{array}{c}\text { Critical } \\
\text { Values 5\% }\end{array}$ & Prob & Information \\
\hline ROA & 0.320780 & -2.948404 & 0.9761 & $\begin{array}{c}\text { Not } \\
\text { Stationer }\end{array}$ \\
INFLATION & -4.739667 & -2.954021 & 0.0006 & Stationer \\
EXCHANGE & -3.507941 & -2.948404 & 0.0136 & Stationer \\
RATE & & -2.948404 & 0.9383 & $\begin{array}{c}\text { Not } \\
\text { Stationer } \\
\text { INTEREST }\end{array}$ \\
RATE & -0.128905 & -2.948404 & 0.0000 & $\begin{array}{c}\text { Stationer } \\
\text { Stationer }\end{array}$ \\
CPI & -5.911315 & -2.986225 & 0.0010 & \\
IPI & -4.704535 & $-1150 f t w a r e$ & &
\end{tabular}

Source: Data processed using views 11 software.

In Table I, the stages of the root test level test show the results of the unit root test using the ADF method at the level. From the table above, various results are obtained, it can be seen in the ROA variable that the results are not stationarily seen from the level of the $t$-statistic value which describes the greater than the critical value of $5 \%$ while the results of the inflation, exchange rate, CPI and IPI variables show that stationary, as seen from the ADF t-statistic value, is smaller than the critical value of MacKinnon / Critical Values 5\%, the prob data shows below 0.05 . Meanwhile, the interest rate variable is not stationary because the ADF statistical value is smaller than the MacKinnon critical value and the probability value is 0.9383 . Therefore, it is necessary to continue with the stationarity test on the first difference.

\section{B. Unit Root Test (First Difference)}

TABLE II: ESTIMATION RESULTS OF AUGMENTED DICKEy FULLER (ADF) ON INTERCEPT-FIRST DIFFERENCE

\begin{tabular}{ccccc}
\hline & \multicolumn{4}{c}{ ADF Statistic } \\
\cline { 2 - 5 } Variable & t-statistic & $\begin{array}{c}\text { Critical } \\
\text { Values 5 \% }\end{array}$ & Prob & Information \\
\hline ROA & -7.084936 & -2.951125 & 0.0000 & Stationer \\
INFLATION & -5.869477 & -2.960411 & 0.0000 & Stationer \\
EXCHANGE & -6.523196 & -2.951125 & 0.0000 & Stationer \\
RATE & & & & \\
INTEREST & -3.278870 & -2.951125 & 0.0239 & Stationer \\
RATE & -5.460387 & -2.963972 & 0.0001 & Stationer \\
CPI & -8.580773 & -2.991878 & 0.0000 & Stationer \\
IPI &
\end{tabular}

Source: Data processed using views 11 software.

Table II shows the estimation results of the unit root at the first difference level for all variables that are stationary. This means that the data used in this study is integrated into order one or can be shortened to I (1) so that the data is free from spurious regression problems. Therefore, the stationary conditions have been met.

\section{Optimal Lag Test}

Determination of the optimum lag in this study using a commonly used method, namely by using the smallest Akaike Information Criterion (AIC) value. Based on the Akaike Information Criterion (AIC) value, the optimum lag length is 1. So, the lag value that will be used for further research is lag 1. The results of determining the lag length are shown in the following tables:

\begin{tabular}{cccccc}
\multicolumn{6}{c}{ TABLE III: OPTIMAL LAG TEST RESULTS } \\
\hline Lag & Logl & LR & FPE & AIC & SC \\
\hline 0 & -447.3832 & NA & $2.28 E+08$ & 36.27066 & 36.56319 \\
1 & -376.5917 & $101.9398^{*}$ & $15436647^{*}$ & $33.48733^{*}$ & $35.53504 *$ \\
\hline Source: Data processed using views & 11 software.
\end{tabular}

Determination of the lag length is done by looking at the values of the Likelihood Ratio (LR), Final Prediction Error (FPE), Akaike Information Criterion (AIC), Schwarz Information Criterion (SC), and HannanQuin Creation (HQ). Determination of the optimal lag using the information criteria is obtained by selecting the criterion that has the smallest value or the most asterisks among the various proposed lags. Therefore, the authors take lag 1 seen from the smallest value on the Likelihood Ratio (LR), Final Prediction Error (FPE), Akaike Information Criterion (AIC), Schwarz Information Criterion (SC), and Hannan Quin Creation (HQ) values.

\section{VAR Model Stability Test}

This study, based on the VAR stability test shown in Table IV, it can be concluded that the estimated stability of the VAR to be used for IRF and FEVD analysis is stable because the modulus range is $<1$. 
TABLE IV: VAR MODEL STABILITY TEST RESULTS

\begin{tabular}{cc} 
TABLE IV: VAR MODEL STABILITY TEST RESULTS \\
\hline Root & Modulus \\
\hline $0.749549-0.181488 \mathrm{i}$ & 0.771208 \\
$0.749549+0.181488 \mathrm{i}$ & 0.771208 \\
0.673627 & 0.673627 \\
-0.237902 & 0.237902 \\
0.106018 & 0.106018 \\
-0.007970 & 0.007970 \\
\hline
\end{tabular}

Source: Data processed using views 11 software.

Based on Table IV shows that the modulus value of all equation models is less than 1 so it can be concluded that the VAR model is valid. Next, the VAR stability test was carried out using the inverse roots $\mathrm{AR}$ characteristic polynomial shown in the following figure:

Inverse Roots of AR Characteristic Polynomial
1.5
1.0
0.5
0.0
-0.5
-1.0
-1.5

Fig. 2. VAR stability test for the equation model using the inverse roots of AR characteristic polynomial.

Based on Fig. 2, the VAR stability test using the inverse roots of AR characteristic polynomial for the equation model shows that the points on the circle or the spread of the data do not go out of the circle, this means that the data is valid for further analysis using VAR. Therefore, the VAR stability test using, and roots of the characteristic polynomial and inverse roots AR characteristic polynomial is valid, which means that the results of the impulse response function and variance decomposition in the VAR estimation are valid.

\section{E. Johans Cointegration Test}

Test to determine the number of 5 cointegration equations is carried out through the Johansen Cointegration test with the optimum lag of 1 in accordance with the determination of the optimum lag based on the AIC that has been done previously. The Johansen Cointegration Test method is carried out by comparing trace statistics with critical values using a significance level of 5 percent. If the trace statistic is greater than the critical value, then there is cointegration in the system of equations.

Table $\mathrm{V}$ shows that the trace statistic valuer $=0$ is greater than the critical value with a significance level of 5 percent, which is 158.0581 greater than 95.75366 for the model the equation of the relationship between ROA and (Inflation, Interest Rates, Exchange Rates, CPI and IPI). This means that the null hypothesis which states that there is no cointegration in the variables used is rejected and the alternative hypothesis which states that there is cointegration is accepted. Thus, the results of the integration test indicate that between movements in inflation, interest rates, exchange rates, the consumer price index (CPI), and the industrial production index (IPI), there is a relationship between stability/balance and the similarity of movements in the long term. Therefore, in any short-run period, all variables tend to adjust to each other to reach their long-run equilibrium. Thus, the appropriate model to be used in this study is the Vector Error Correction Model (VECM) not Variance Autoregression (VAR) because the variables used are cointegrated and stationary at the first difference level. This is a requirement that must be met in testing the VECM.

TABLE V. EQUATION MOdEl COINTEGRATION TEST RESUlts (ROAMACRO VARIABLES)

\begin{tabular}{ccccc}
\multicolumn{5}{c}{ MACRO VARIABLES) } \\
\hline $\begin{array}{c}\text { Unrestriced Cointegration Rank Test (Trace) } \\
\text { Hypothesized }\end{array}$ Eigenvelue & $\begin{array}{c}\text { Trace } \\
\text { Statistic }\end{array}$ & $\begin{array}{c}0.05 \\
\text { Critical } \\
\text { Value }\end{array}$ & Prob** \\
\hline None* & 0.940729 & 158.0581 & 95.75366 & 0.0000 \\
At most $1 *$ & 0.820795 & 90.24300 & 69.81889 & 0.0005 \\
At most 2* & 0.540587 & 48.98159 & 47.85613 & 0.0390 \\
At most 3* & 0.469109 & 30.31425 & 29.79707 & 0.0436 \\
At most 4 & 0.345876 & 15.11750 & 15.49471 & 0.0569 \\
At most 5* & 0.185709 & 4.930489 & 3.8414465 & 0.0264 \\
Unrestricted Cointegration Rank Test (Maximum Eigenvalue) \\
None* & 0.940729 & 67.81511 & 40.07757 & 0.0000 \\
At most 1* & 0.820795 & 41.26141 & 33.87687 & 0.0055 \\
At most 2 & 0.540587 & 18.66734 & 27.58434 & 0.4407 \\
At most 3 & 0.469109 & 15.19675 & 21.13162 & 0.2754 \\
At most 4 & 0.345876 & 10.18701 & 14.26460 & 0.1999 \\
At most 5* & 0.185709 & 4.930489 & 3.841465 & 0.0264 \\
\hline Source: Data processed using views 11 software.
\end{tabular}

\section{F. Grenger Causality Test}

Test Bivariate causality test in this study used the VAR Pairwise Granger Causality Test and used a five percent significance level. The following table presents the results of the analysis of the Bivariate Granger Causality test.

\begin{tabular}{cccc}
\multicolumn{4}{c}{ TABLE VI: GRANGER CAUSALITY TEST RESUlTS } \\
\hline Null Hypothesis & OBS & F-Statistic & Prob. \\
\hline $\begin{array}{c}\text { INFLASI does not Granger Cause } \\
\text { ROA }\end{array}$ & 35 & 0.19935 & 0.6583 \\
$\begin{array}{c}\text { ROA does not Granger Cause } \\
\text { INFLASI }\end{array}$ & 35 & 0.04182 & 0.8393 \\
SB does not Granger Cause ROA & 35 & 3.28027 & 0.0795 \\
ROA does not Granger Cause SB & 35 & 1.09100 & 0.3041 \\
KURS does not Granger Cause ROA & 35 & 3.14946 & 0.0855 \\
ROA does not Granger Cause KURS & 35 & 0.01519 & 0.9027 \\
IHK does not Granger Cause ROA & 35 & 15.9059 & 0.0004 \\
ROA does not Granger Cause IHK & 35 & 0.05039 & 0.8238 \\
IPI does not Granger Cause ROA & 35 & 0.00067 & 0.9796 \\
ROA does not Granger Cause IPI & 35 & 1.43241 & 0.2441 \\
\hline
\end{tabular}

From the results obtained above, it is known that those who have a causal relationship are those that have a probability value smaller than alpha 0.05 so that later Ho will be rejected, which means a variable will affect other variables. From the Granger test above, we know the reciprocal/causality relationship as follows:

- The inflation variable does not statistically affect the ROA variable with a Prob value of 0.6583 (rejected the null hypothesis) and the ROA variable does not statistically affect the Inflation variable with a Prob value of 0.8393 (rejected the hypothesis). zero)

- The interest rate variable statistically does not affect the ROA variable with a value of Prob 0.0795 (rejected the null hypothesis) and the ROA variable does not statistically affect the interest rate varies with a value of Prob 0.3041 (rejected the null hypothesis)

- The exchange rate variable does not statistically affect the ROA variable with Prob value 0.0855 (rejected the null 
hypothesis) and the ROA variable statistically does not affect the Exchange rate variable with a Prob value of 0.9027 (rejected the null hypothesis)

- The CPI variable statistically affects the ROA variable with a Prob value of 0.0004 (accepted the null hypothesis) and the ROA variable statistically does not affect the CPI variable with a value of Prob 0. 8238 (zero hypotheses rejected)

- The IPI variable does not statistically affect the ROA variable with a Prob value of 0.9796 (rejected the null hypothesis) and the ROA variable does not statistically affect the IPI variable with a Prob value of 0.2441 (rejected the null hypothesis)

\section{G. Estimation Model VECM}

Estimation VECM Estimation Results Influence of variable indicators of inflation, interest rates, exchange rates, cpi, and ipi on banking performance After testing cointegration on the VAR system, it is proven that all equations in this study are cointegrated and can be continued using the VECM model.

TABLE VII. VECM MODEL ESTIMATION TEST LONG-TERM AND SHORTTERM ESTIMATION OF THE EQUATION MODEL (ROA - MACRO VARIABLE)

\begin{tabular}{cccc}
\hline Variable & Koefesien & T-statistic & Information \\
\hline LONG TERM & & & \\
ROA & 1.000000 & & \\
INFLATION & -0.020101 & {$[-0.63554]$} & SIGNIFICANT \\
EXCHANGE RATE & -0.060235 & {$[-4.36854]$} & SIGNIFICANT \\
INTEREST RATE & 0.000127 & {$[5.62654]$} & SIGNIFICANT \\
CPI & 0.018617 & {$[4.63724]$} & SIGNIFICANT \\
IPI & -0.000192 & {$[-12.2651]$} & SIGNIFICANT \\
SHORT TERM & & & \\
ROA -1 & -0.559214 & {$[-1.89921]$} & SIGNIFICANT \\
INFLATION -1 & -0.020768 & {$[-0.28259]$} & SIGNIFICANT \\
EXCHANGE RATE & 0.050626 & {$[0.50041]$} & SIGNIFICANT \\
-1 & $1.65 E-05$ & {$[0.24013]$} & SIGNIFICANT \\
INTEREST RATE - & NOT \\
1 & 0.003287 & {$[0.63846]$} & SIGNIFICANT \\
CPI -1 & $-2.45 E-05$ & {$[-0.86120]$} & SIGNIFICANT \\
IPI -1 &
\end{tabular}

Source: Data processed using views 11 software.

Based on the results of the VECM Model Estimation Test in Equation 1 (ROA - macro variable) in Table VII, where the long-term and short-term relationship on the ROA variable is the variables of inflation, interest rates, exchange rates, CPI, and IPI are concluded as follows:

- ROA has a negative and significant relationship to the inflation variable in a long-term relationship. This means that if inflation in the long term increases by 1 percent, it will be followed by a decrease in the ROA variable. this also occurs in the short-term relationship has a negative and significant effect

- ROA has a negative and significant relationship to the Interest Rate variable in the long-term relationship. This means that if the long-term interest rate increases by 1 percent, it will be followed by a decrease in the ROA variable. this is reversed with a positive and significant short-term relationship. This means that if the interest rate in the long term increases by 1 percent, it will be followed by an increase in the ROA variable.

- ROA has a positive and significant relationship to the exchange rate variable in a long-term relationship. This means that if the long-term exchange rate increases by 1 percent, it will be followed by an increase in the ROA variable. this also occurs in the short-term relationship where there is a positive and insignificant relationship between ROA and the exchange rate. This means that if the exchange rate increases by 1 percent in the short term, it will not be followed by an increase in the ROAROA variable.

-Has a positive and significant relationship with the CPI variable in the long-term relationship. This means that if the $\mathrm{CPI}$ in the long term increases by 1 percent, it will be followed by an increase in the ROA variable. this also occurs in the short-term relationship where the relationship is positive and significant.

- ROA has a negative and significant relationship to the IPI variable in a long-term relationship. This means that if the IPI in the long term increases by 1 percent, it will be followed by a decrease in the ROA variable. this also occurs in the shortterm relationship has a negative and insignificant effect. This means that if the IPI in the short term increases by 1 percent, it will not be followed by an increase in the ROA variable.

\section{H. Analysis of Impulse Response Function (IRF)}

The analysis will explain the impact of the shock on one variable on another variable, which in this analysis is not only in the short term but can analyze for several future horizons as long-term information.

Response to Cholesky One S.D. (d.f. adjusted) Innovations

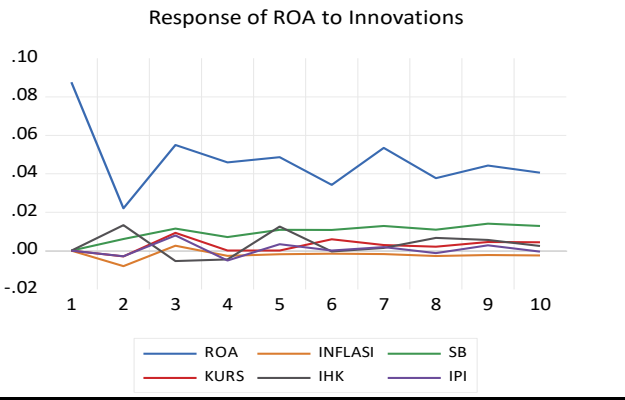

Fig. 3. ROA response due to shock from inflation, interest rates, exchange rates, CPI, and IPI.

Fig. 3 above shows that the ROA response to shocks of other variables fluctuates. Shock Inflation with a negative value of one standard deviation was immediately responded to by ROA in the second period. Then the ROA value will decrease by 0.022034 . and period 3 experienced an increase and period 4 to 10 was negative.

Then, on the other hand, the response of the ROA variable to the interest rate shock on a change of one standard deviation moves quite significantly and tends to be positive. In the first period, it appears that the ROA variable has responded, the response is given in the second period to the 10th period which has fluctuated. The positive response of ROA to interest rate shocks occurs at a ROA of one standard deviation, it will cause the IPI to rise to the third period worth 0.054934 .

Response of the ROA variable to the shock of the exchange rate on a change of one standard deviation is quite significant and tends to be positive but there was a shock in the second period with a negative value which resulted in a shock to the ROA of 0.022034 .

The response of the ROA variable to the CPI shock at a change of one standard deviation is quite significant and tends 
to be positive, while the CPI in the 3rd period tends to be negative until the 4th and 6th periods. the ROA response experienced a shock in the $3 \mathrm{rd}$ period was positive with a value of 0.054943 .

The response of the ROA variable to the IPI shock at a change of one standard deviation is quite significant and has a negative value in the second period of the shock that occurred, given IPI to the ROA concurrently as shown in Figure 1 in the graph. from period 1 to period 10 fluctuated so that it was followed by the ROA response to IPI.

\section{Analysis of Variant Decomposition (VD)}

Analysis of VD (Varian Decomposition) aims to measure the composition or contribution of the influence of the independent variable on the dependent variable. In this study, VD analysis was focused on seeing the effect of the independent variables (Inflation, Interest Rates, Exchange Rates, CPI, and IPI) on the dependent variable (ROA).

\begin{tabular}{|c|c|c|c|c|c|c|c|}
\hline Period & S.E. & ROA & INFLASI & SB & KRS & IHK & IPI \\
\hline 1 & 0.087649 & 100.0000 & 0.000000 & 0.000000 & 0.000000 & 0.000000 & 0.000000 \\
\hline 2 & 0.091993 & 96.51582 & 0.768471 & 0.438101 & 0.108443 & 2.068186 & 0.100982 \\
\hline 3 & 0.108615 & 94.82331 & 0.607402 & 1.429160 & 0.803835 & 1.735586 & 0.600712 \\
\hline 4 & 0.118364 & 94.89399 & 0.564880 & 1.560218 & 0.676947 & 1.611747 & 0.692220 \\
\hline 5 & 0.129094 & 93.96493 & 0.495188 & 2.020244 & 0.569101 & 2.300765 & 0.649773 \\
\hline 6 & 0.134126 & 93.55633 & 0.472810 & 2.512635 & 0.723858 & 2.132385 & 0.601982 \\
\hline 7 & 0.145010 & 93.62553 & 0.419294 & 2.929486 & 0.660277 & 1.833706 & 0.531710 \\
\hline 8 & 0.150429 & 93.29465 & 0.423515 & 3.247904 & 0.632688 & 1.899714 & 0.501528 \\
\hline 9 & 0.157629 & 92.84599 & 0.406020 & 3.750387 & 0.656512 & 1.853770 & 0.487323 \\
\hline 10 & 0.163361 & 92.60438 & 0.401698 & 4.110738 & 0.681224 & 1.747412 & 0.454544 \\
\hline
\end{tabular}

Source: Data processed using views 11 software.

Variance Decomposition using Cholesky (d.f. adjusted) Factors

Variance Decomposition of ROA

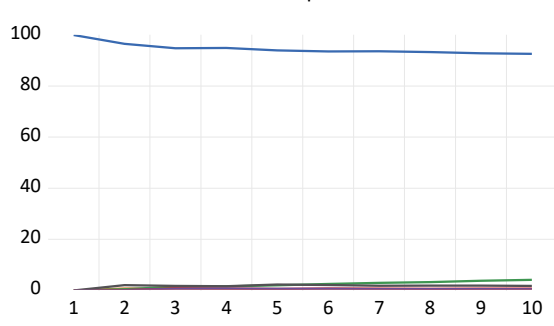

ROA
KURS INFLASI
IHK

Fig. 4. ROA response due to the influence of inflation, interest rates, exchange rates, CPI, and IPI.

Based on the estimation results, Table VIII shows the contribution of macroeconomic variables (Inflation, Interest Rates, Exchange Rates, CPI, and IPI) to bank performance indicators (ROA). In the estimation above, it can be concluded that the largest contribution to banking performance variables is obtained from the performance variable itself. However, in terms of macroeconomic variables that contributed the highest to ROA, namely interest rates in the 10th period with a value of $4.11 \%$, followed by CPI in the 5th period with a value of $2.30 \%$, Inflation in the second period with a value of $0.76 \%$, the exchange rate in the 6th period with a value of $0.72 \%$ and at the end is the IPI with a value of $0.69 \%$ in the 4 th period.

\section{J. Relationship Between Financial Variables (ROA) and Economic Activity}

The estimation consequences above withinside the long time ROA have a poor and extensive courting with inflation in a long-time period courting, this means that according to Sukarno (2006:14), inflation is a manner of growing costs winning in something economy. Increased inflation will motive the actual fee of financial savings to say no due to the fact human beings will use their wealth to fulfill charges because of growing costs of products for you to have an effect on financial institution profitability in this situation ROA. In line with the idea defined via way of means of Sukarno, namely, while inflation takes place it's going to have an effect on the saving made via way of means of the network, in which human beings spend greater for intake than saving cash withinside the financial institution. As a result, the financial institution's Third Party Funds (TPF) will revel in a decline that allows you to lessen financial institution profits. This idea indicates that as a proxy for inflation, it has a poor and extensive courting with ROA. High inflation may have an effect on human beings's earnings and additionally costs will boom and those will be supposed to shop cash and could have an effect on banking overall performance in this situation go back on banking assets.

The long-time period courting of the ROA variable has a poor and extensive courting with the Interest Rate variable. According to Bank Indonesia, hobby fees are rules that mirror the economic coverage stance set via way of means of Bank Indonesia as a reference in economic operations via handling liquidity withinside the cash marketplace to obtain operational targets. economic coverage. The use of the BI Rate as a reference in figuring out the equal reasons adjustments in hobby fees which additionally have an effect on the profitability of banks and the extent of non-appearing financing (chance of default). will create a coverage sample to withdraw budget from the network to steer the network in depositing their cash to the financial institution that allows you to have an effect on banking profitability in this situation ROA. So, the BI charge is simplest an attraction or reference and now no longer a law that need to be implemented via way of means of financial institution management. In addition, the charge does now no longer have an effect on financial institution hobby fees without delay however as an alternative impacts financial institution hobby fees via the Interbank Money Market (PUAB).

The actual change charge is the relative rate of products among countries. The actual change charge states the charge at which we will change items from one united state for items from some other united states. If the actual change charge decreases, home items are highly inexpensive than overseas items, thereby growing the extent of home funding. A boom in funding call for will lessen the delivery of home foreign money invested abroad. When the home change charge appreciates, items emerge as greater high priced relative to 
overseas items and internet exports fall. This proves that the change charge (Exchange charge) will decide the go back on actual funding. A growing foreign money will manifestly boom the buying energy of the earnings and capital earned from any kind of funding. This boom in funding will have an effect on the financial institution's operational activities.

With the boom in funding, the call for for financing from banks can even boom and eventually will have an effect on the financial institution's economic ratios, one in all that's the profitability ratio represented via way of means of ROA

The estimation results above in the long-term ROA has a positive and significant relationship with the CPI, which means that when inflation occurs, it will result in consumption being spent by people who need very large funds. The increase in public consumption will affect the savings made by the community, where people spend more on consumption than saving money in the bank. As a result, the bank's Third Party Funds (TPF) will experience a decline which will reduce bank profits. This theory shows that the CPI as a proxy for inflation has a positive relationship with ROA.

When the long-term ROA variable has a negative and significant relationship with the IPI variable. IPI is a macroeconomic indicator to measure the real production output of the industrial sector. The Industrial Production Index is usually compiled to measure the increase and decrease in production which is a proxy for Gross Domestic Product (GDP) which describes national income. If the national income is increased, it will increase the company's profits, because the increase in company income has no effect on people's incomes, with high public incomes, the saving pattern of people in banking will increase. This theory shows that IPI has a negative relationship to ROA.

The results of the short-term estimation, ROA has a negative and significant relationship with inflation. In the sense that if the increase in inflation will result in a decrease in profitability, namely the short-term ROA ratio.

Short-term estimation results, ROA has a positive and significant relationship with interest rates. where this policy is regulated by the central bank which has an impact on the banking structure when interest rates are raised in a ratio, it will have an impact that makes people save money.

This proves that the exchange rate (Exchange rate) will determine the return on real investment. A rising currency will obviously increase the purchasing power of the income and capital earned from any type of investment. However, in this study, the results showed that the short-term estimation results, ROA had a negative and insignificant relationship with the exchange rate. in the sense that the exchange rate can be shifted into a currency that increases will clearly increase people's purchasing power which also results in the ROA ratio having an impact on people's purchasing power and being reluctant to save money.

The results of the short-term estimation, ROA has a positive and significant relationship with the CPI. When inflation occurs, it will cause consumption expenditure by the public to increase, the pattern of public consumption will increase as well as the pattern of saving so that an increase in the CPI which is a proxy for inflation in the short term will make bank profitability increase so that the ROA of banks also increases along with the increase in CPI.
VECM estimation results short-term relationship between ROA and IPI. When short-term ROA has a negative but not significant relationship to IPI at lag1. The Industrial Production Index is a macroeconomic indicator released by the board of the US Federal Reserve Bank, measuring changes in the total value of inflation-adjusted for production output from producers, mining companies, and the gas industry. IPI is a proxy for Gross Domestic Product (GDP) which describes national income seen from the industrial production sector. When the increase in national income will affect the company's income and result in an increase in people's income. However, in the short term, the increase in national income is not fully responded to by the public by changing the pattern of saving or the desire to save money so that in the short-term case, ROA in banking does not increase in line with the increase in IPI in a country or ROA has no relationship with IPI. in the short term. In terms of the contribution of macroeconomic variables (Inflation, Interest Rates, Exchange Rates, CPI, and IPI) on bank performance indicators (ROA) In the estimation above, it can be concluded that the largest contribution to the banking performance variable is obtained from the performance variable itself. However, in terms of macroeconomic variables that contributed the highest to ROA, namely interest rates in the 10 th period with a value of $4.11 \%$, followed by CPI in the 5 th period with a value of $2.30 \%$, Inflation in the second period with a value of $0.76 \%$, the exchange rate in the 6 th period with a value of $0.72 \%$ and at the end is the IPI with a value of $0.69 \%$ in the 4 th period.

\section{CONCLUSION AND SUGGESTION}

\section{A. Conclusion}

Based on the results of the long-term VECM estimation, the ROA variable has a negative and significant relationship with Inflation, Interest Rates, and IPI. Then ROA has a positive and significant relationship with the exchange rate and CPI. While the short-term VECM estimate of ROA has a negative and significant relationship to inflation, positive and significant to interest rates and the CPI, but the exchange rate has a positive and non-significant relationship while the IPI has a negative and non-significant relationship.

Based on the IR results, it shows that the ROA response to shocks of other variables fluctuates. Shock Inflation is negative from the 2 nd period and is immediately responded to by the ROA variable until it enters the 3rd period, then interest rates increase from the 3 rd period, then the ROA variable responds directly to the shock given by interest rates, the exchange rate goes hand in hand with ROA graphically shown in periods 1 to 10 and the ROA response to CPI is inversely related and also IPI to ROA is responded to from periods 1 to 6 .

Based on the VD results in terms of the contribution of macroeconomic variables (Inflation, Interest Rates, Exchange Rates, CPI, and IPI) to bank performance indicators (ROA) In the estimation above, it can be concluded that the largest contribution to banking performance variables is obtained from the performance variable itself. However, in terms of macroeconomic variables that contributed the highest to ROA, namely interest rates in the 10th period with a value of 
$4.11 \%$, followed by CPI in the 5 th period with a value of $2.30 \%$, Inflation in the second period with a value of $0.76 \%$, the exchange rate in the 6th period with a value of $0.72 \%$ and at the end is the IPI with a value of $0.69 \%$ in the 4 th period.

\section{B. Suggestion}

Based on the findings in this study, several suggestions can be made, including:

1. For the government / Bank Indonesia as policymakers, it is necessary to have a policy scheme that aims to control the course of the banking performance system so that it remains on track, it is necessary to expand the study of macroprudential in terms of research and research with more innovative models, more variables and simple that is wider. As well as in an effort to stabilize the financial system and banking stability to pay more attention to and control the movement of macroeconomic variables of inflation, interest rates, and exchange rates. CPI and IPI. These five variables have been proven to contribute significantly to macroeconomic conditions in the long term and in other words, are significantly related to the Bank's performance.

2. For banking companies in Indonesia, this study found that the exchange rate contributed to macroeconomic conditions or other findings on bank performance. So that Indonesian banks need to increase their attention in determining every policy taken due to the uncertainty that occurs in the exchange rate, especially the Rupiah exchange rate against the US Dollar in the last few years. In addition, Indonesian banks must also consider the effects of inflation more in determining management strategies, considering that in this study inflation was proven to contribute significantly to macroeconomic conditions and also interest rates which became bank policies in an effort to create stability in banking performance.

3. For further researchers, it can emphasize the use of thirdparty fund financing ratios as a benchmark for assessing bank performance (FDR). This is because in this study it has not been explained too deeply and in order to add insight and be more dominant in contributing to varied research results. In addition, researchers can consider the use of other macroeconomic variables such as the unemployment rate, national investment, and the Dow Jones index as well as global oil prices.

\section{REFERENCES}

[1] Aviliani, Siregar H., Maulana T.N.A., Hasanah H. "The Impact of Macroeconomic Condition on The Banks Performance in Indonesia," Bul Ekon Monet Dan Perbank, vol. 17, pp. 379-402, 2015. https://doi.org/10.21098/bemp.v17i4.503.

[2] [2] Abusomwan Success, "Macroeconomic Performance and Performance Nexus Banking Industry: An Perfectual Evidence From Nigeria," Glob J Manag Bus Res E Mark, vol. 18, pp. 33-41, 2018.

[3] S., Mehar A. Riaz, "Impact of Bank Specific and Macroeconomic Variables on the Performance of Commercial Banks of Nepal," Rom Econ J, vol. 16:, pp. 1-110, 2013.

[4] U. Kingdom, C. N. Simiyu, L. Ngile, "Effect of Macroeconomic Variables on Profitability of Commercial Banks Listed in the Nairobi Securities Exchange," Int J Econ Commer Manag,vol. III, pp. 1-16, 2015.

[5] J. Peyavali, S. Sheefeni, "The Macroeconomic Determinants of Profitability among Commercial Banks in Namibia," J Emerg Issues Econ Financ Bank, vol. 4, pp. 1414-31, 2015.

[6] S. Widyaningrum, "Analysis the Effect of Macroeconomic Indicators and Specific-Firm Characteristic as Determinant Profitability of Islamic Banks in Asia," Glob Rev Islam Econ Bus, vol. 2, pp. 85-97,
2014.

[7] Y. C. Pratama, "Macroeconomic Variable and It's Influence On Performance of Indonesian Islamic Banking," Al-Iqtishad J Ilmu Ekon Syariah, vol. 7, pp. 59-72, 2015.

[8] M. A. Emase, Effect of Macroeconomic Factors on The Profitability of Commercial Banks Listed at The Nairobi Securities Exchange in Kenya. KCA University, 2017.

[9] L. Isaac, "Assessing the Impact of Exchange Rate Risk on Banks Performance in Nigeria," J Econ Sustain Dev, vol. 6, pp.1-13, 2015.

[10] A. Combey, A. Togbenou, "The Bank Sector Performance and Macroeconomics Environment: Empirical Evidence in Togo," Int $J$ Econ Financ, vol. 9, pp. 180-8, 2017. https://doi.org/10.5539/ijef.v9n2p180.

[11] E. O. Kiganda, "Effect of Macroeconomic Factors on Commercial Banks Profitability in Kenya: Case of Equity Bank Limited.," J Econ Sustain Dev, vol. 5, pp. 46-56, 2014.

[12] I. O. Osamwonyi, C. I. Michael, "The Impact of Macroeconomic Variables on the Profitability of Listed Commercial Banks In Nigeria," Eur J Account Audit Financ Res, vol. 2, pp. 85-95, 2014.

[13] B. P. Neupane, "Profitability Determinants of Nepalese Commercial Banks," Press Procedia, vol. 1, pp. 40-5, 2020. https://doi.org/10.17261/pressacademia.2020.1345.

[14] A. Akbar, H. Thamrin, "Analysis of Effect of CAPR, DAR, ROA and Size on Tax Avoidance," Dinasti Int J Manag Sci, vol. 1, pp. 706-18, 2020. https://doi.org/10.31933/dijms.v1i5.285.

[15] S. Gerlach, W. Peng, C. Shu, "Macroeconomic Conditions and Banking Performance in Hong Kong SAR: A Panel Data Study," BIS Pap, vol. 22, pp. 481-97, 2003.

[16] A. Al-Harbi, "The Determinants of Conventional Banks Profitability in Developing and Underdeveloped OIC Countries," J Econ Financ Adm Sci, vol. 24, pp. 4-28, 2019. https://doi.org/10.1108/JEFAS-05-20180043 .

[17] M. Ekananda, "Analysis of the Macroeconomic Impact towards the NPL National Banking in Indonesia: The Study," Eur Res Stud J, vol. 20, pp. 396-416, 2017. https://doi.org/10.35808/ersj/717.

[18] D. Clichici, T. Colenicova, "The Impact of Macroeconomic Factors on Non-Performing Loans in The Republic of Moldova," J Financ Monet Econ, vol. 1, pp. 73-8, 2014.

[19] A. Hakim, Statistika Deskriptif untuk Ekonomi dan Bisnis. Yogyakarta: Ekonisia; 2006.

[20] Boediono. Seri Sinopsis Pengantar Ilmu Ekonomi No.1 2014:222.

[21] N. Huda, H. R. Idris, M. E. Wiliasih, Ekonomi Makro Islam: Pendekatan Teoritis, 2018.

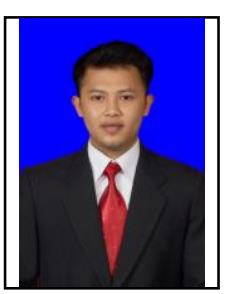

Tegar Prasetya was born in Jakarta on November 9 1992. He is 29 years old. He started his first bachelor's degree at Pancasila University with a major in accounting. He started his career as an auditor in several accounting firms. He decided to take a master's degree at Mercu Buana University to gain knowledge and to have a career. It was a big decision in the possibility that it would change everything. 